\title{
Competitive Advantage in Cost Leadership and Differentiation of SMEs "Bakoel Zee" Marketing Strategy in BSD
}

\author{
Marissa Grace Haque ${ }^{1}$, Munawaroh ${ }^{2}$, Denok Sunarsi ${ }^{3}$, Aris Baharuddin ${ }^{4}$ \\ ${ }^{1}$ Department of Management, Indonesia Banking School, Jakarta, Indonesia \\ ${ }^{2}$ Indonesian Education University, Bandung, Indonesia \\ ${ }^{3}$ Universitas Pamulang, Tangerang Selatan, Banten, Indonesia \\ ${ }^{4}$ Universitas Negeri Makassar, Makassar, Indonesia \\ Email: marissa.haque@ibs.ac.id ${ }^{1}$,_nawa@upi.edu ${ }^{2}$, denoksunarsi@unpam.ac.id ${ }^{3}$,
} aris.baharuddin@unm.ac.id

(Received: January-2021; Reviewed: February-2021; Accepted: March-2021;

Avalaible Online: March-2021; Published: March-2021)

c) (i) (2) This is an open access article distributed under the Creative Commons Attribution License EY CC-BY-NC-4.0 (C2021 by author (https://creativecommons.org/licenses/by-nc/4.0/)

\begin{abstract}
The purpose of this study was to measure the strategy implementation of cost leadership and differrentiation to its competitive advantage in the SMEs culinary business. The design or method which is used in this study is a multiple linear regression statistical analysis by the independent variable (X) products Nasi Bakoel as Cost leadership (X1) and product Dimsum as Differrentiation (X2). While the dependent variable (Y) Total Sales as its competitive advantage. The findings of this study is simultaneously cost leadership and differentiation positive and significant impact on the competitive advantage, while individually the effect is greater than the cost leadership differentiation to competitive advantage. This research is also expected to be a reference for further studies with similar problems in the future.
\end{abstract}

Keywords: Culinary; SMEs; marketing strategies; Bakoel Zee.

\section{INTRODUCTION}

Culinary business is one kind of business that nowadays had been developing so much and holds quite a huge potential for growth. There have been many examples of successful people who benefited from this kind of businesses. Though it doesn't mean there aren't cases of unsuccessful attempts due to bad marketing strategies and the lack of good services. This means that the success of a culinary business in winning a competition was influenced by accurate marketing strategies and also a good connection or relation with the customers (Ahmad et al., 2015; Akib et al., 2015; Budi et al., 2015; Limpo et al., 2015; Papilaya et al., 2015; Rengifurwarin et al., 2018; Syam et al., 2018). 
Even though there's no particular limit to a culinary business, the increasing number of restaurants in Indonesia could be a parameter to determine the development of this business. According to the data from BPS (2017), the total of culinary business players in Indonesia has been increasing every year but with declining growth. The biggest growth is at $27,7 \%$ in 2013 , but slows down the following years until finally it's at 2,07 percents in 2016.

Table 1. The Total of Restaurant (Big and Middle Scale) in Indonesia

\begin{tabular}{ll}
\hline Year & Total \\
\hline $\mathbf{2 0 1 2}$ & 1.615 \\
$\mathbf{2 0 1 3}$ & 2.235 \\
$\mathbf{2 0 1 4}$ & 2.704 \\
$\mathbf{2 0 1 5}$ & 2.916 \\
$\mathbf{2 0 1 6}$ & 2.977 \\
\hline
\end{tabular}

Source: BPS (2017)

Culinary business in Indonesia was dominated by small scale to middle scale businesses. According to GPMMI in Jawapos (2017), 70 percents of the players in this industry are small to middle scale businesses. In South Tangerang itself, at least there are 5.000 units of those small to middle scale businesses, 50 percents of it were dominated by food industries (Skalanews, 2017). Culinary business was considered to be the top choices among people, as it seemed easier than any other types of businesses (Sakaguchi et al., 2018). This, in fact, is not quite true as this business relies on a lot of innovations and a sustainable creativity.

The tight competition, pushed companies to determines the most suitable marketing strategies for them so they could stays in the game. Each companies must have had different strategies to reach a competitive benefits. There are 3 general strategies that companies tend to use as a struggle to develop their business in a tight competition in order to reach and maintain competitive benefits. Porter (1997) mentioned those 3 strategies as Differentiation Strategy, Cost Leadership, and Focus. Cost Leadership is a strategy in which by reducing the cost so that the output costs will end up being lower than the companies who applied Differentiation Strategy and Focus.

Cost Leadership Strategy helps allow the company to reach larger benefits because that company could pressed down the production cost thus resulting in a more competitive price and will raise the profits (Ahidin et al., 2020; Sunarsi, 2014b, 2014a, 2017, 2018; Sunarsi \& Erlangga, 2020). In other words, the performance of that company will be better. (Valipour et al.,(2012) explained that a company who applied the Cost Leadership Strategy had its financial leverage, business strategy and dividends payout had positive influences toward the company's performances.

The rise of company's performance who applied Cost Leadership Strategy was accomplished by a strict control of costs. A company should work to minimize the costs in every aspects of business. In this case, the company should emphasizes on efficiency where that company produces a large volume of standard products.

The purpose of this research is to measure the application of Cost Leadership Strategy and Differrentiation Strategy towards the benefits of competing in culinary business exclusively the "Bakoel Zee" SMEs which had a rapid development. This research is done descriptively by trying to analyze a culinary business phenomenon which caused a stir in South Tangerang and South Jakarta area. A similar research had been done by Sancoko (2015) on culinary business development strategies of "Time to Eat" depot in Surabaya. 


\section{Hypothesis}

Low cost strategy and Differentiation strategy were applied by companies to reach competitive advantage than the other competitors in the market (Barney, 1995; Day \& Nedungadi, 1994; Flint, 2000; Jogaratnam, 2017; Klein, 2002; Kuncoro \& Suriani, 2018; Pfeffer, 1994). With that in mind, there is an influence of low cost strategy and differentiation strategy towards the advantages a company hoped to gain. As with previous explanation, the research design that should be born is as follow:

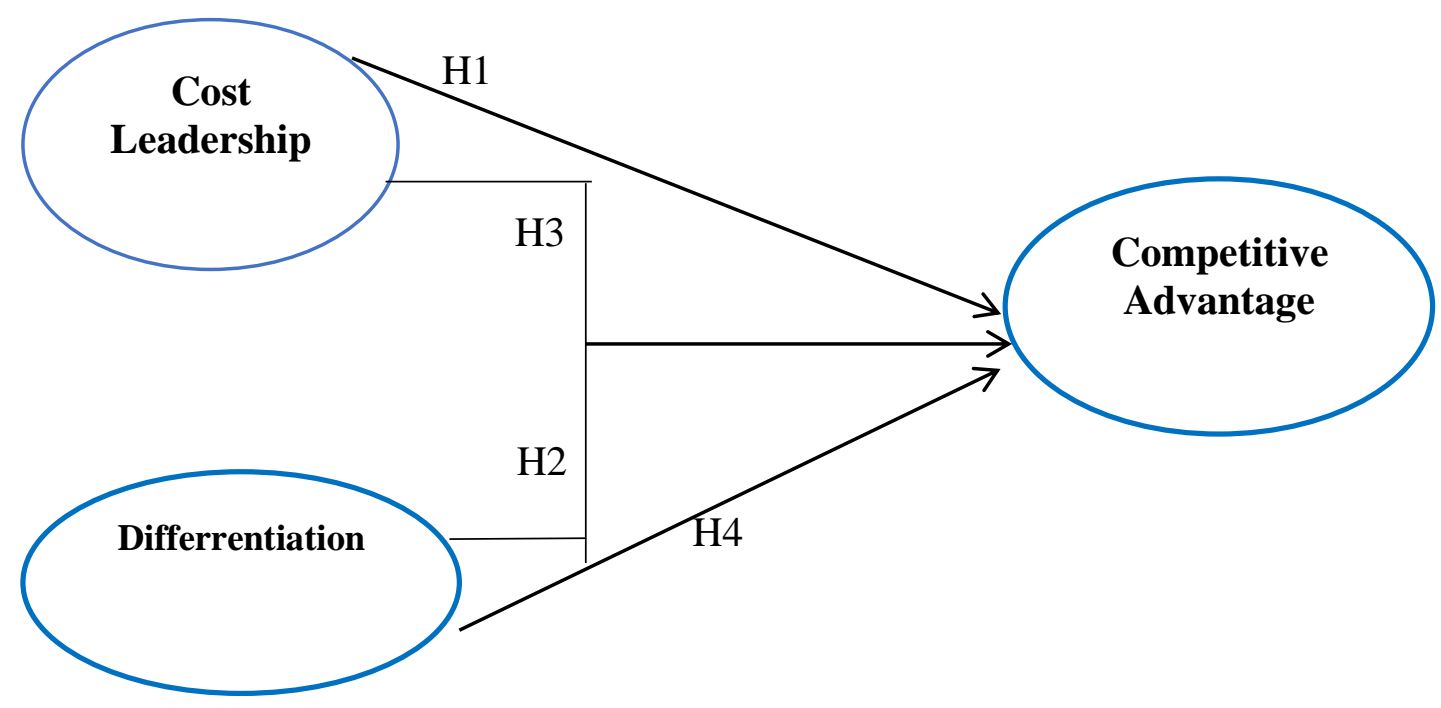

picture 1. Research Design

This research's hypothesis are:

1. There's a significant influence of Cost Leadership Strategy towards a competitive advantages

2. There's a significant influence of Differentiation Strategy towards a competitive advantages

3. There's a significant influence of both Cost Leadership and Differentiation towards a competitive advantages

\section{METHOD}

This research was done descriptively focusing on cases which are detailed researches of an object in particular range of time, done deeply in a complete manner and make use of various data as resources (Hancock \& Algozzine, 2006). In the correlation with time and place, the object of the studies is contemporary, which is still happening or already done but left many impacts and influences (strong or particular) when the study begins (Yin, 2003). Yin also said that the most suitable case study of this research is one which had no control over events.

\section{Variable Operationalization}

1. Cost Leadership

Cost Leadership is a formula which is used to determine the main burden of production which in turn resulted in lower cost to grab a particular market segment (L. W. Porter et al., 1974; M. E. Porter, 1997). 
2. Differentiation

Differentiation in this study is the presence of uniqueness from a product that could be compared from similar products from other businesses (Hilman \& Kaliappen, 2014).

3. Competitive Advantage.

Competitive Advantage is a result of strategy application by a company with these indication: resulting products, segment of market gained, or market share gained (Bharadwaj et al., 1993).

\section{Analysis and Explanation}

There are 2 products to become this research variables: 1) BAKOEL ZEE Nasi Bakoel is Cost Leadership variable due to its cheaper price than other business's product like SINBAD, Abu Nawas, Abu Salim, and even compared to the other menu inside the restaurant itself, and 2) BAKOEL ZEE DIMSUM and variances is Differentiation variable due to its unique presence that no other SMEs had.

The data that are used in this research came from sales data from May to July 2016. The sum comes in 84 data from the outlet in BSD, Banten.

\section{RESULT AND DISCUSSION}

\section{Regression Result}

Before conducting the regression method to the research models, the hypothesis which resulted in this was done as follows:

$$
\text { Total Sales }=1941063.148+1.876 F N C+2.135 F N P+E
$$

Table 2. Regression Result

\begin{tabular}{lrrrrr}
\multicolumn{6}{c}{ Model Summary $^{\mathbf{b}}$} \\
\hline Model & R & R Square & $\begin{array}{c}\text { Adjusted } \\
\text { R Square }\end{array}$ & $\begin{array}{c}\text { Std. Error of the } \\
\text { Estimate }\end{array}$ & $\begin{array}{c}\text { Durbin- } \\
\text { Watson }\end{array}$ \\
\hline 1 & & & R Squar & \\
\hline
\end{tabular}

a. Predictors: (Constant), SALESBZNB, SALESBZDS

b. Dependent Variable: TOTALSALES

Going by the output above, we can see that the value of DW is 2.217 . Next this value will be compared with the value of significant table $(5 \%)$, the total of samples $(\mathrm{N}=82)$, and the total of independent variables $2(K=2)=2.82$. Then we get the value of du 1.6913. The value of DW is 2.217 times larger than the limit $(\mathrm{du})$ which is 1.6913 and less than $(4-\mathrm{du}) 4-1.6913=2.3087$. Se we can conclude that there are no autocorrelation in the above regression models.

\section{Simultaneous Influence Test (F-test)}

F-test or usually called Simultaneous test and Anova test, is used to watch the influence of all independent variables towards dependent variables. F-test is also used as an indicator as to whether the regression model is significant or not. This test use level of significance with 1 percent, 5 percents and 10 percents of probability. The criteria for receiving area $\left(\mathrm{H}_{0}\right)$ or 
rejection in F-test were done by comparing F-test with degree of numerator (k) and degree of denominator $(\mathrm{n}-1-\mathrm{k})$, where $\mathrm{n}$ is the sum of all samples and $\mathrm{k}$ is the sum of all independent variables in this test. With samples as many as $\mathrm{n}=82$, df denominator $=79$ and df numerator $=$ 2. From the distribution table, we get the value of Ftable $=4.88$ for $\alpha=1$ percent, 3.11 with $\alpha=5$ percents and, Ftable $=2.37$ with $\alpha=10$ percents. The value of Fstat which is larger than Ftabel, shows that there is a significance influence between independent variables together towards dependent variables.

Table 3. Simultaneous Influence Test (F-test)

\begin{tabular}{lrrrrr}
\multicolumn{6}{c}{ ANOVA $^{\mathbf{a}}$} \\
\hline Model & Sum of Squares & df & Mean Square & F & Sig. \\
\hline Regression & 2339310751882097.000 & 2 & 1169655375941048.500 & 839.765 & $.000^{\mathrm{b}}$ \\
1 Residual & 110034034666683.270 & 79 & 1392835881856.750 & & \\
Total & 2449344786548780.500 & 81 & & & \\
\hline
\end{tabular}

a. Dependent Variable: TOTALSALES

b. Predictors: (Constant), SALEBZNB, SALESBZDS

The table above shows that there is a value of probability Fstat is 0,000 smaller than $\alpha=1$ percent. Thus we can conclude that the value Fstat is significant.

\section{The Result of Testing the Hypothesis of Time Series Equivalent Model}

The testing was done by observing the significance of correlation from each dependent variables. On the table below, shows that the positive value of coefficient depicted that the dependent variable stands perpendicular towards the variables that influenced it. On the other side, the negative value of coefficient depicted that the dependent variable stands inversely towards the variables that influenced it.

\section{Table 4. Result of Testing the Hypothesis}

Coefficients $^{\mathbf{a}}$

\begin{tabular}{|c|c|c|c|c|c|c|c|c|}
\hline \multirow{2}{*}{\multicolumn{2}{|c|}{ Model }} & \multicolumn{2}{|c|}{ Unstandardized Coefficients } & \multirow{2}{*}{$\begin{array}{c}\begin{array}{c}\text { Standardized } \\
\text { Coefficients }\end{array} \\
\text { Beta }\end{array}$} & \multirow[t]{2}{*}{$\mathrm{T}$} & \multirow[t]{2}{*}{ Sig. } & \multicolumn{2}{|c|}{$\begin{array}{c}\text { Collinearity } \\
\text { Statistics }\end{array}$} \\
\hline & & B & Std. Error & & & & Tolerance & VIF \\
\hline \multirow{3}{*}{1} & (Constant) & 1941063.148 & 358370.358 & & 5.416 & .000 & & \\
\hline & SALESNKL & 1.876 & .121 & .658 & 15.566 & .000 & .318 & 3.145 \\
\hline & SASALESNKABM & 2.135 & .250 & .360 & 8.523 & .000 & .318 & 3.145 \\
\hline
\end{tabular}

a. Dependent Variable: TOTALSALES

Going by the table above, it was discovered that BZNB sales free variables reach the value of 1.876 with positive value which means BZNB sales had a positive influences towards the overall sales. The same goes with BZDS sales which got the positive value of 2.135 which means that BZDS sales also had a positive influences towards the overall sales

According to the result of regression analysis, we get the value of $t$ is $15.566>t$ table 1.984 and the value of significance is $0.000<0.05$. Thus we can conclude that $\mathrm{H} 0$ is rejected while $\mathrm{H} 1$ is accepted which means BZNB sales had a significance influence towards the overall sales. Meanwhile, with BZDS sales free variable it was discovered that the vlue of $t$ is $8.523>t$ table 1,984 and the significance value is $0.000<0.05$. So we can say that $\mathrm{H} 0$ is rejected and $\mathrm{H} 1$ is accepted, which means just like BZNB sales, BZDS sales also had a significance influence towards the overall sales. 


\section{CONCLUSION}

Using F-test, it was proven that Cost leadership which used Bakoel Zee Nasi Bakul and Differentiation which used Bakoel Zee Dim Sum simultaneously had a positive influence and significance toward the Competitive Advantage. While individually, using T-test, it was proven that Cost leadership had a positive influence and significance toward the Competitive Advantage. Also Differrentiation had a positive influence and significance toward the Competitive Advantage.

\section{REFERENCES}

Ahidin, U., Abidin, A. Z., Halomoan, Y. K., Permatasari, R. J., \& Sunarsi, D. (2020). Pelatihan Dasar Kepemimpinan Milenial Karang Taruna Kelurahan Pamulang Barat. BAKTIMAS: Jurnal Pengabdian Pada Masyarakat, 2(1), 72-76.

Ahmad, K., Dirawan, G. D., Akib, H., Kahar, F., \& Malik, T. (2015). Knowledge problem of collaboration in regional development planning (case in Mamuju regency). International Journal of Applied Business and Economic Research, 13(4).

Akib, H., Rifdan, \& Guntur, M. (2015). Quality improvement strategies of academic services and student affairs at the Graduate Program State University of Makassar, Indonesia. International Journal of Applied Business and Economic Research, 13(4).

Barney, J. B. (1995). Looking inside for competitive advantage. Academy of Management Perspectives, 9(4), 49-61.

Bharadwaj, S. G., Varadarajan, P. R., \& Fahy, J. (1993). Sustainable competitive advantage in service industries: a conceptual model and research propositions. Journal of Marketing, 57(4), 83-99.

Budi, R., Akib, H., Jasruddin, \& Dirawan, G. D. (2015). Public information management services in South Sulawesi. International Journal of Applied Business and Economic Research, 13(4).

Day, G. S., \& Nedungadi, P. (1994). Managerial representations of competitive advantage. Journal of Marketing, 58(2), 31-44.

Flint, G. D. (2000). What is the meaning of competitive advantage? Journal of Competitiveness Studies, 8(1), 121.

Hancock, D. R., \& Algozzine, B. (2006). A practical guide for beginning researchers doing case study research. New York: Teachers College Press.

Hilman, H., \& Kaliappen, N. (2014). Market orientation practices and effects on organizational performance: Empirical insight from Malaysian hotel industry. Sage Open, 4(4), 2158244014553590 .

Jogaratnam, G. (2017). The effect of market orientation, entrepreneurial orientation and human capital on positional advantage: Evidence from the restaurant industry. International Journal of Hospitality Management, 60(1), 104-113.

Klein, J. (2002). Beyond competitive advantage. Strategic Change, 11(6), 317.

Kuncoro, W., \& Suriani, W. O. (2018). Achieving sustainable competitive advantage through product innovation and market driving. Asia Pacific Management Review, 23(3), 186-192. 
Limpo, H. Y., Akib, H., \& Dirawan, G. D. (2015). Policy formulation for the initiative right of people's representative councilof South Sulawesi. International Journal of Applied Business and Economic Research, 13(4).

Papilaya, J., Soisa, T. R., \& Akib, H. (2015). The influence of implementing the strategic policy in creating business climate, business environment and providing support facilities towards business empowerment on small medium craft enterprises in Ambon Indonesia. International Review of Management and Marketing, 5(2).

Pfeffer, J. (1994). Competitive advantage through people. Boston/Mass.

Porter, L. W., Steers, R. M., Mowday, R. T., \& Boulian, P. V. (1974). Organizational commitment, job satisfaction, and turnover among psychiatric technicians. Journal of Applied Psychology, 59(5), 603.

Porter, M. E. (1997). Competitive strategy. Measuring Business Excellence.

Rengifurwarin, Z. A., Akib, H., Jasruddin, \& Salam, R. (2018). Snapshot of public service quality in the center for integrated business service (CIBS), cooperative micro small and medium enterprises (CMSME), Maluku province, Indonesia. Journal of Entrepreneurship Education, 21(3).

Sakaguchi, L., Pak, N., \& Potts, M. D. (2018). Tackling the issue of food waste in restaurants: Options for measurement method, reduction and behavioral change. Journal of Cleaner Production, 180, 430-436.

Sancoko, A. H. (2015). Strategi Pengembangan Bisnis Usaha Makanan dan Minuman Pada Depot Time To Eat Surabaya. Agora, 3(1), 185-194.

Sunarsi, D. (2014a). Pengaruh Gaya Kepemimpinan, Disiplin dan Motivasi Terhadap Kinerja. Tesis. Fakultas Ekonomi Universitas Pamulang.

Sunarsi, D. (2014b). Pengaruh Gaya Kepemimpinan, Motivasi dan Disiplin Kerja Terhadap Kinerja Pendidik. Universitas Pamulang.

Sunarsi, D. (2017). Pengaruh Kepemimpinan Dan Budaya Organisasi terhadap Kinerja Karyawan Pada Cabang Pembantu Bank DKI Pondok Labu - Jakarta Selatan. JENIUS, $1(2), 21$.

Sunarsi, D. (2018). Pengaruh Gaya Kepemimpinan, Motivasi Dan Disiplin Kerja Terhadap Kinerja Pendidik Yayasan Marvin. Inovasi, 5(1), 1-18.

Sunarsi, D., \& Erlangga, A. (2020). The Effect of Leadership Style and Work Environment on the Performance of Stationary Pump Operators in the Water Resources Office of West Jakarta City Administration. International Journal of Advances in Social and Economics, 2(3).

Syam, H., Akib, H., Patonangi, A. A., \& Guntur, M. (2018). Principal entrepreneurship competence based on creativity and innovation in the context of learning organizations in Indonesia. Journal of Entrepreneurship Education, 21(Special Issue).

Valipour, H., Birjandi, H., \& Honarbakhsh, S. (2012). The effects of cost leadership strategy and product differentiation strategy on the performance of firms. Journal of Asian Business Strategy, 2(1), 14-23.

Yin, R. K. (2003). Designing case studies. Qualitative Research Methods, 359-386. 
284 Pinisi Discretion Review

Volume 4, Issue 2, March 2021 Page. 277- 284 